\title{
THE LONG ROAD TO HUMAN RIGHTS COMPLIANCE
}

\section{Francesca Klug, Professorial Research Fellow, Centre for the Study of Human Rights, London School of Economics and Political Science* $^{*}$}

\section{Introduction: The Ancien Regime}

Ten years ago the protection of human rights in the UK rested on the common law. A decade ago the guarantor of our freedoms was the "sovereignty of Parliament" whereby "Parliament has, under the English constitution, the right to make any law whatever and ... no person or body ... ha[s] a right to override or set aside the legislation of Parliament."

How these two propositions could be fully reconciled was never adequately explained. But the result, according to ministers at the time, was an almost mystical enhancement of freedom.

"This country's approach to rights and freedoms is more permissive than found elsewhere. The possession of rights and freedoms is assumed. It is not dependent on their enshrinement in statute or through some other constitutional devise."2

Or in the words of former Prime Minister Mrs Thatcher:

"The Government considers that our present constitutional arrangements continue to serve us well and that the citizens in this country continue to enjoy the greatest degree of liberty that is compatible with the rights of others and the vital interests of the state."

This is not to imply that the courts had no powers to check the actions and decisions of the executive. From the 1970s in particular, the courts gradually extended the degree to which, and the circumstances within which, they would hold public bodies to account. The Wednesbury approach to judicial review, developed in a case involving Sunday cinema performances and the Wednesbury Corporation, established that a decision could only be overturned on substantive, rather than procedural, grounds where it was "unreasonable". ${ }^{4}$ The "burden of proof" on an individual to establish that ministers or officials had acted "beyond the range of responses open to a reasonable decision-maker" was very high. ${ }^{5}$

* With much appreciation to Helen Wildbore for her excellent research and meticulous assistance.

1 A. V. Dicey, Introduction to the Study of the Law of the Constitution (10 ${ }^{\text {th }}$ edition), Macmillan, 1959, at 70.

2 Charles Wardle, Home Office Minister, 225 HC 1029, (27 May 1993).

3 Letter to Baroness Ewart-Biggs, 26 May 1989.

4 Associated Provincial Picture Houses Ltd v Wednesbury Corporation [1948] 1 KB 223.

$5 R$ v Ministry of Defence ex. p. Smith [1996] QB 517 at 554 
By the mid 1990s the courts had developed the so-called "flexible Wednesbury" principle, through which, it was maintained, fundamental rights, like life, should be subject to "the most anxious scrutiny". 6 This was most strongly articulated in the Court of Appeal in Smith, which challenged the automatic dismissal of gay men and lesbians from the military, where it was maintained that:

"The more substantial the interference with human rights, the more the court will require by way of justification before it is satisfied that the decision is reasonable."

However, although the Appeal Court judges expressed varying degrees of discontent with the reasons for the expulsions advanced by the Ministry of Defence, none were prepared to label the policy "irrational". ${ }^{8}$ The case had to proceed to the European Court of Human Rights in Strasbourg before the policy was declared a breach of fundamental rights and overturned by the government. ${ }^{9}$

Lord Bingham summed up what is now the ancien regime of human rights enforcement in the UK:

"It is, inevitably, common ground that the United Kingdom's obligation, binding in international law, to respect and ensure compliance with [the Convention] is not one that is enforceable by the domestic courts. The relevance of the Convention in the present context is as background to the complaint of irrationality. The fact that a decision-maker fails to take account-of Convention obligations when exercising an administrative discretion is not of itself a ground for impugning the exercise of that discretion." 10

As for reviewing primary legislation, prior to the Human Rights Act (HRA) this was effectively off limits. In case after case, the courts confirmed that the use of the European Convention on Human Rights (ECHR) as a guide to statutory interpretation was only applicable where there was an ambiguity in legislation. Even then, a breach of the Convention was said to have no greater significance than a breach of foreign law. ${ }^{11}$ Research I conducted in 1996 suggested that the ECHR influenced the interpretation of legislation in only 11 of the 316 cases in which the Convention was cited in the English courts from $1975 .{ }^{12}$

\section{The Stated Aims of the Human Rights Act}

In 1998 the HRA was introduced by the new Labour Government in line with its 1997 manifesto commitment to incorporate the ECHR into UK law.

6 Bugdaycay v Secretary of State for the Home Department [1987] AC 514, at 531.

$7 R$ v Ministry of Defence, ex. p. Smith [1996] 1 All ER 257 at 263.

8 ibid.

9 Smith and Grady v UK (1999) 29 EHRR 493.

10 See $\mathrm{n} .7$ at 266.

11 Per Lord Nolan, $R$ v Khan [1996] 3 All ER 289 at 302.

12 Seven of these cases involved the interpretation of legislation passed specifically to comply with adverse decisions in Strasbourg. See Francesca Klug and Keir Starmer, "Incorporation through the Back Door?" [1997] Public Law 223. 
This followed a long campaign for a Bill of Rights to address the deficiencies in human rights protection of relying on a combination of the common law and parliamentary sovereignty to protect fundamental rights. ${ }^{13}$ The HRA came into force with the new millennium, in October 2000. This "ridiculous law" 14 or "cranks charter" 15 was greeted by howls of ridicule and warnings of dire consequences by much of the press and a number of political and legal commentators. Columnist Peter Oborne, was not alone in viewing the Act as evidence of the contempt the new Labour government was showing to:

"the institutions that define our existence as a nation ... The real effect of this month's incorporation of the European Convention on Human Rights into English law is the replacement of the Common Law, unchallenged since the Middle Ages, with a codified European model."'16

The government, on the other hand, proclaimed the significance of the Act. Jack Straw, the then Home Secretary, claimed it provided "the first Bill of Rights this country has seen for three centuries". ${ }^{17}$ Three broad reasons were given by the government for taking this momentous step.

First, to "bring rights home" so that individuals in the UK could "assert and enforce their rights under the ECHR through the ordinary UK courts and tribunals". ${ }^{18}$ This would "enable individuals to use the UK courts to prevent and remedy the misuse of public power" which is "the primary purpose of incorporating the ECHR". ${ }^{19}$

Second, to address what was argued to be a "democratic deficit" in the British political system whereby executive accountability consisted mainly of periodic elections and limited scope for judicial review (see above). Along with other proposals for constitutional reform, the Human Rights Act was claimed to:

$$
\begin{aligned}
& \text { "strengthen representative and democratic government...by } \\
& \text { enabling citizens to challenge more easily actions of the state if } \\
& \text { they fail to match the standards of the European } \\
& \text { Convention." } 20
\end{aligned}
$$

Third, to build "a culture of rights and responsibilities in the UK. These aren't empty words or mere jargon. A rights and responsibilities culture really is our goal ... . we didn't incorporate the Convention principles and norms as playthings for lawyers. . . in time, the language of the Convention

13 This was primarily an elite-led campaign led largely by Charter 88 and other proconstitutional reform NGOs, lawyers and political commentators, largely on the left of the political spectrum.

14 The People, 22 October 2000

15 Daily Mail, 2 October 2000.

16 Sunday Express, 15 October 2000.

17306 HC 769 (16 February 1998).

18 Bringing Rights Home: Labour's plans to Incorporate the ECHR into UK Law, Labour Party consultation document, 1996, p.11.

19 ibid, p.8.

20 See n.17 above. 
will be the language in which many of the key debates are settled...And that's a real culture change." 21

Prime Minister Tony Blair put it this way:

"The Act...requires all of us in public service to respect human

rights in everything we do." 22

To assess the impact of the HRA on compliance with human rights norms in the broadest sense, each of these stated aims need to be evaluated in turn.

\section{Bringing Rights Home: Compliance in the Courts}

It was not long before the first effects of the HRA on the judicial process were apparent. Out of 431 cases in which the ECHR was cited by the higher courts in the first eighteen months of the Act's life (over a hundred more than in the previous two decades), it was estimated that the HRA affected the outcome, reasoning and procedure in $318 .^{23}$

Yet predictions of clogged up courts and a new litigious culture did not materialise, at least not as a consequence of the HRA. Early research by the Lord Chancellor's Department (LCD) indicated that very few cases at any level were wholly reliant on the HRA. ${ }^{24}$ Then, as now, the HRA is mainly cited as a defence in criminal trials or as an additional argument in judicial reviews or torts. By July 2001 Lord Steyn warned against:

"unfounded predictions that the 1998 Act would cause chaos in our legal system. A healthy scepticism ought to be observed about practised predictions of an avalanche of dire consequences likely to flow from any new development ..."25

\section{Unexpected Decisions}

Failing to head the warning of Professor David Feldman, former legal advisor to the Joint Committee on Human Rights (JCHR), that "Convention rights are unlikely to operate in a purely liberal and individualistic way", there were numerous early cases that confounded the expectations of both the opponents and proponents of the HRA. ${ }^{26}$ The assumption, based on a "black letter" reading of the ECHR, that the Human Rights Act would usher in a

21 Jack Straw, "Building a Human Rights Culture", Address to Civil Service College Seminar, 19 December 1999.

22 Conventional Behaviour: questions about the HRA, an introduction for public authorities, Home Office, 1999.

23 An HRA claim was upheld in 94 cases and remedies of some kind awarded in 91. These figures are based on research by the Human Rights Act Research Project which I directed until 2003. See Francesca Klug and Claire O’Brien, “The First Two Years of the HRA," [2002] Public Law 649.

24 See Craig Raine and Clive Walker, "The Impact on the Courts and the Administration of Justice of the Human Rights Act 1998" (October 2002) which found relatively limited impact of the HRA on the courts in terms of challenges and additional workload, although it had invoked a number of significant policy and practice changes and was felt to be engendering a stronger human rights culture within the courts.

$25 R$ v Lambert [2001] UKHL 37, at para.30.

26 David Feldman, "The Human Rights Act 1998 and Constitutional Principles", 19(2) Legal Studies 165 (1999) at 173. 
new era of libertarianism was first jolted by the drink-driving case of Brown. ${ }^{27}$ This concerned the use of self-incriminating evidence by car owners and drivers under section 172 of the Road Traffic Act 1988. The court found that the Act was not a disproportionate response to the high incidence of death and injury on the roads and that submitting a driver's admission at trial did not undermine Article 6, the right to a fair hearing. The Privy Council recognised that, inherent in the Convention, is the need to establish the correct balance between the protection of individual rights and the interests of the community at large.

In Clingham, where the use of hearsay evidence in the granting of an ASBO was also challenged as a breach of Article 6, the court held that ASBO proceedings had the features of a civil rather than criminal hearing and that hearsay evidence was therefore admissible. Lord Hutton said:

"[T]he striking of a fair balance between the demands of the general interest of the community and the requirements of the protection of defendants' rights requires the scales to come down in favour of the protection of the community." 28

In Marper the retention and use by the police of DNA samples and fingerprint evidence after a suspect had been acquitted was found to be compatible with the ECHR. ${ }^{29}$ The evidence, the court heard, was only kept for the limited purpose of the detection, investigation and prosecution of crime and would not be made public. When balanced against the enormous advantages conferred by the expansion of the database in the fight against serious crime, the House of Lords determined, the practice was not disproportionate in effect.

There have been numerous other cases, unsurprisingly, whose outcome has disappointed human rights advocates and activists, often involving procedural issues concerning the ambit of Article 6. ${ }^{30}$ Perhaps the most surprising and disturbing of these was the Court of Appeal ruling that evidence obtained by torture abroad could be relied upon in domestic courts, provided that UK officials were not involved in obtaining it. This decision was subsequently overturned by the House of Lords, the majority of the Lords ruling that the Special Immigration Appeals Commission should not admit evidence if it concludes on the balance of probabilities that it was obtained by torture. ${ }^{31}$

27 Brown v Procurator Fiscal and Advocate General for Scotland [2001] 2 WLR 817. It was held that the jurisprudence of the European Court of Human Rights very clearly established that whilst the overall fairness of a criminal trial could not be compromised, the constituent rights contained in Art.6 of the Convention, whether explicit or implicit, were not themselves absolute.

28 Clingham v Kensington and Chelsea LBC; $R$ (McCann) v Manchester Crown Court [2002] UKHL 39 at para.113.

29 Arts.8 and 14. $R(L S)$ v Chief Constable of South Yorkshire Police; $R$ (Marper) $v$ Chief Constable of South Yorkshire Police [2004] UKHL 39.

30 Matthews v Ministry of Defence [2003] UKHL 4; Begum v Tower Hamlets [2003] UKHL 5; D v East Berkshire Community Health NHS Trust [2005] UKHL 23.

31 The Lordships ruled that Article 15 of the Convention Against Torture, which prohibits the use of evidence established to have been obtained by torture in proceedings, cannot be understood to apply only where the state in whose 
However, any meaningful evaluation of the degree to which the HRA has fulfilled the intention of 'bringing rights home' needs to look beyond the results of individual cases to the impact the HRA has had more generally on the system for protecting rights within the UK.

\section{Judicial Review}

Before incorporation, the European Court of Human Rights described the British system as one that:

"effectively excluded any consideration by the domestic courts of the question of whether the interference with applicants' rights answered a pressing social need or was proportionate ...." 32

This polite but damning indictment of the Wednesbury reasonableness doctrine as an adequate protection of fundamental rights was effectively endorsed by the House of Lords in Daly, ${ }^{33}$ which provided its verbal death throes, at least where Convention rights are at stake. ${ }^{34}$ Lord Cooke predicted that:

"the day will come when it will be more widely recognised that ... Wednesbury ... . was an unfortunately retrogressive decision in English administrative law, in so far as it suggested that there are degrees of reasonableness and that only a very extreme degree can bring an administrative decision within the legitimate scope of judicial invalidation." ${ }^{35}$

Lord Steyn, whilst cautioning against confusing his approach with a "merits review" in which the courts substitute their own judgement for that of the primary decision-maker, observed that "there is a material difference between the Wednesbury and proportionality grounds of review". ${ }^{36} \mathrm{He}$ suggested three concrete differences. First, the doctrine of proportionality may require the reviewing court to assess the balance that the decision maker had struck, not merely whether it is within the range of rational or reasonable decisions. Second, the proportionality test may go further than the traditional grounds of review in as much as it may require attention to be directed to the relative weight accorded to interests and considerations. Third, even the "heightened scrutiny" (or "flexible Wednesbury") test is not necessarily appropriate to the protection of human rights:

"The intensity of the review . . . is guaranteed by the twin requirements that the limitation of the right was necessary in a democratic society, in the sense of meeting a pressing social

jurisdiction the proceedings are held has inflicted or been complicit in the torture. A v Secretary of State for the Home Department (no 2) [2004] EWCA Civ 1123 and $A$ v Secretary of State for the Home Department [2005] UKHL 71.

32 Smith \& Grady v UK, see n.9 above.

$33 R$ (Daly) v Secretary of State for the Home Department [2001] 2 WLR 1622.

34 The point here being that, under the Convention doctrine of proportionality, the measure adopted by the decision-maker must be that which is the least intrusive of the protected right, while still achieving the legitimate aim in question.

35 ibid at 1636-37.

36 ibid at 1634. 
need, and the question whether the interference was really proportionate to the legitimate aims pursued." 37

Steyn's approach has been broadly followed in a string of successive cases. In Wilkinson the Court of Appeal authorised the attendance of doctors for cross examination to assess whether the administration of medical treatment without the consent of a detained mental health patient was proportionate. ${ }^{38}$ In Prolife Alliance Lord Justice Laws held that a constitutional responsibility lay on the court's shoulders to decide for itself whether interference with a fundamental right was justified, the UK now being "long past the point" where a public authority's "bare demonstration of rationality or reasonableness" would be sufficient. ${ }^{39}$ The strongest demonstration to date of the transformative effects of importing the doctrine of proportionality through the HRA was provided in the case of $A$. This involved the courts reviewing the Anti-Terrorism Crime and Security Act 2001 for compatibility with the ECHR, something the courts were effectively constitutionally barred from doing prior to 2000. The House of Lords concluded that the power to indefinitely detain without trial foreign nationals in Part 4 of the Act was disproportionate; it discriminated on grounds of nationality or immigration status without achieving its stated aim of preventing terrorism. ${ }^{40}$

\section{The Common Law and Horizontal Application}

The development of the common law in line with the HRA has been a little more uneven. Naomi Campbell's privacy case against the Mirror group newspapers confirmed what the case law until then had already established; that the HRA did not create any new 'cause of action' between private parties (sometimes referred to as "horizontal application"). However the courts, as public authorities under section 6 of the Act, must interpret all law compatibly with Convention rights, including the common law as it applies between private individuals. ${ }^{41}$

This is clearly what was envisaged by Lord Irvine, the Lord Chancellor, when the HRA was introduced:

". . . it is right as a matter of principle for the courts to have the duty of acting compatibly with the Convention, not only in cases involving other public authorities, but also in developing the common law in deciding cases between individuals." ${ }^{42}$

The widespread prediction that the HRA thereby would in time fill the lacuna left by the systems failure to protect personal privacy has not yet materialised. This gap was described by Lord Bingham as "the failure of both the common law of England and statute to protect in an effective way the personal privacy of individual citizens". ${ }^{43}$

37 ibid at $1635-36$.

${ }^{38} R$ (on the application of Wilkinson) v Responsible Medical Officer Broadmoor Hospital [2002] 1 WLR 4.

$39 R$ (on the application of Prolife Alliance) v $B B C$ [2002] 2 All ER 756 at 33 and 36.

40 A v Secretary of State for the Home Department [2004] UKHL 56.

41 Campbell v MGN Ltd [2004] UKHL 22.

42583 HL 783 (24 November 1997).

43 Kaye v Robertson [1991] FSR 62. 
Although it was recognised in Douglas that the HRA stopped short of full "horizontal" effect, ${ }^{44}$ in that only public authorities are directly liable for Convention breaches under HRA section 7 and section 8 , the courts were held to have a "positive obligation", in appropriate cases, to develop the common law to protect privacy rights. ${ }^{45}$ Lord Justice Sedley even observed that "we have reached a point at which it can be said with confidence that the law recognises and will appropriately protect a right of personal privacy". ${ }^{46}$

However when footballer Garry Flitcroft tried to gag publication of details of his alleged extramarital affairs, the Court of Appeal was categorical that privacy claims would be brought, not as new privacy actions, but through the tort of breach of confidence. ${ }^{47}$ The court's section 6 duty would be met by "absorbing the rights which Articles 8 and 10 protect," into this action, giving it "new strength and breadth . . . so that it accommodates the requirements of those articles", which would "in the great majority of situations, if not all . . . provide the necessary protection." 48 This selfimposed limitation arguably falls short of 'bringing privacy rights home' but this interpretation is almost certainly liable to further development by the courts.

A further protection gap between the Strasbourg and English courts concerning horizontal application has opened up through the definition of 'public authority' under the HRA developed in the Poplar Housing ${ }^{49}$ and Leonard Cheshire Foundation ${ }^{50}$ cases. These suggested that certain governmental features had to apply before a body could be classified under the HRA ${ }^{51}$ as a public authority "certain of whose functions are functions of a public nature" (sometimes referred to as 'hybrid bodies'). These features relate to the closeness of the body to the institutions of the state, for example whether it exercises statutory powers, rather than the functions the body performs and whether the state would be under a duty to provide them if the body in question did not.

In the more recent case of Aston Cantlow, Lord Hope developed a wider and more functional approach to defining "hybrid bodies" noting that the purpose of the HRA is to "bring rights home" and provide a domestic remedy where Strasbourg would find a breach of the Convention. ${ }^{52}$ The broader requirements of Articles 1 and 13 of the Convention, which are not included in the Convention Rights incorporated into domestic law through the HRA, sometimes require the state to put in place a legal framework which prevents or responds to breaches of Convention rights even when the person or body

44 Douglas v Hello! Ltd [2001] QB 967 see para.81.

45 ibid at 88-91.

46 ibid at 110.

47 A and B, sub nom Garry Flitcroft v Mirror Group Newspapers Ltd [2002] 2 All ER 545.

48 ibid at para.4 and 11. See also Francesca Klug and Claire O'Brien n.23 at 654-657.

49 Poplar Housing and Regeneration Community Association v Donoghue [2001] EWCA Civ 595.

50 Callin, Heather and Ward v Leonard Cheshire Foundation [2002] EWCA Civ 366.

51 S.6(3)(b)

52 Aston Cantlow and Wilmcote with Billesley Parochial Church Council v Wallban [2004] 1 A.C. 546. 
responsible is not a public authority or performing a "public function". 53 In making his observation, Lord Hope was echoing the intentions behind the drafting of HRA section 6 as clarified by Home Secretary, Jack Straw, when piloting the Human Rights Bill through Parliament:

"The principle of bringing rights home suggested that liability in domestic proceedings should lie with bodies in respect of whose actions the UK Government were answerable in Strasbourg ... We decided that the best approach would be reference to the concept of a public function ... One of the things with which we had to wrestle was the fact that many bodies, especially over the past 20 years, have performed public functions which are private, partly as a result of privatisation and partly as a result of contracting out...The courts will consider the nature of a body and the activity in question." 54

As the JCHR observed in its report, The Meaning of Public Authority under the Human Rights Act ${ }^{55}$ it is not yet clear that the functional approach of the House of Lords in Aston Cantlow is being applied by the lower courts. Organisations like Age Concern, Help the Aged and the Disability Rights Commission, concerned that many vulnerable people in private or charitable residential homes or day care are unprotected by the HRA, have been lobbying government to intervene in a relevant case or clarify the definition of public authority in the promised Single Equality Act. ${ }^{56}$ The government has now committed itself to addressing this issue. ${ }^{57}$

53 These requirements are often grouped and referred to as "positive obligations" on the state. Examples where the domestic courts have generously endorsed the "positive obligations" doctrine include Bernard v Enfield London Borough Council [2003] H.R.L.R. 4 where the court held that Article 8 ECHR placed an obligation on the council to "take positive steps ... to enable [a severely disabled woman and her family living in local authority housing]. . .to lead as normal a family life as possible" (para.33). In $R$ (A and B) v East Sussex County Council [2003] E.W.H.C. 167 (Admin) the court applied the separate opinion of Judge Greve in Price v UK (2001) 34 E.H.R.R. 1285 and said "[i]n order to avoid discriminating against the disabled...one may need to treat the disabled differently precisely because their situation is significantly different from that of the ablebodied...the positive obligation on the State to take reasonable and appropriate measures to secure the rights of the disabled . . . calls for human empathy and humane concern as society seeks to try and ameliorate and compensate for the disabilities faced by persons in A and B's situation." (Para.93.).

54314 HC 406-410 (17 June 1998). See also Francesca Klug, "The Human Rights Act 1998, Pepper v Hart and all that," [1999] Public Law 246 at 255-259.

55 Seventh Report of 2003-04 Session (2004). See also Francesca Klug and Keir Starmer "Standing Back from the HRA: how effective is it five years on?" [2005] Public Law 716.

56 The Women and Equality Unit in the DTI is carrying out a Discrimination Law Review with the aim of drafting a new Single Equality Act to integrate and streamline current anti-discrimination and equality legislation for which the Westminster Parliament has responsibility. The HRA is included in this review in so far as it interacts with the equality enactments.

57 See, for example, Baroness Ashton: "the Government are committed to look for a case in which to address the issues . . . it is possible for us to look more closely 


\section{Statutory Interpretation and Declarations of Incompatibility}

The new rule of statutory interpretation in section 3 of the HRA - that primary and subordinate legislation must "so far as it is possible to do so" be "read and given effect in a way which is compatible with the Convention rights" - is a significant departure from the past. Prior to the HRA, statutory review outside the context of EU law, was virtually non-existent. Where a compatible interpretation is not "possible", higher courts can make a "declaration of incompatibility" under section 4(2) HRA. In similar circumstances, subordinate legislation can be set aside, unless "primary legislation prevents removal of the incompatibility". ${ }^{58}$

According to Lord Irvine, the Lord Chancellor, section 3 was intended to go:

"far beyond the [then] present rule. It will not be necessary to find an ambiguity. On the contrary, the courts will be required to interpret legislation so as to uphold the Convention rights unless the legislation itself is so clearly incompatible with the Convention that it is impossible to do so." $" 59$

This was intended as a "strong form" of incorporation. ${ }^{60}$

Following a series of bold but controversial early decisions, it soon became apparent that the HRA's scheme has the capacity to alter law and practice to give substantive protection to individual rights. ${ }^{61}$ The courts have applied section 3 to "read down" over-broad legislation, ${ }^{62}$ re-interpret provisions to provide new safeguards, ${ }^{63}$ or give a statutory provision a meaning it would not ordinarily bear. ${ }^{64}$ It also became clear that the courts are most likely to apply section 3 forthrightly to re-interpret legislation where their own powers are at issue, ${ }^{65}$ and are least likely to do so where questions of resource allocations or decisions outside their traditional expertise are at stake. ${ }^{66}$

Compared to the early days of HRA jurisprudence, ${ }^{67}$ a reasonably consistent consensus has now emerged on the judicial interpretation of HRA section 3 and its interrelationship with section 4 . On the one hand, although it is clear

and carefully at whether we might do more to address the immediacy of the problem.” HL Deb, 19 October 2005.

58 HRA s.3 (2)(c).

59 "Lord Irvine, The Development of Human Rights in Britain under an Incorporated Convention on Human Rights"\#,[1998] Public Law 221 at 228.

${ }^{60}$ Lord Chancellor, 582 HL 1230 (3 November 1997).

61 See, e.g. R. $(H)$ v Mental Health Review Tribunal [2002] Q.B. 1 and the remedial order (Mental Health Act 1983 (Remedial) Order 2001, S.I. 2001 No. 3712) made following the court's declaration of incompatibility. Additionally, the Secretary of State for Health approved an ex gratia scheme for compensation of those who had been affected.

${ }^{62} R$ v $A$ (No. 2) [2001] 3 All ER 1.

$63 \quad R$ v Offen [2001] 1 WLR 253.

64 N.25 at 81.

$65 R$ v Offen, n.63; R. v A (No. 2$)$ n.62.

${ }^{66}$ Re W and B (Children) (Care Plan), Re W (Children) (Care Plan), above n.29; see also $R$ (Reynolds) v Secretary of State for Social Security [2002] EWHC 426 (Admin); though $c f . R(H)$ v Mental Health Review Tribunal, n.61.

67 See in particular Lord Steyn and Lord Hope in $R v A$ [2002] 1 AC 45, paras. 44 and 108 . 
that "section 3 itself is not free from ambiguity", 68 there is now broad agreement that what Lord Steyn calls an "excessive concentration on the linguistic features of the [statute to be interpreted]", should be substituted in favour of a "purposive" approach concentrating on "the importance of the fundamental right involved". ${ }^{69}$ As Lord Nicholls has pointed out, once it is accepted that section 3 was intended to supersede the pre-HRA legislative ambiguity principle of re-interpretation, Parliament cannot intend the courts to "depend critically upon the particular form of words adopted by the parliamentary draftsman" in the legislation in question without making the application of section 3 "something of a semantic lottery". ${ }^{70}$

On the other hand, Lord Steyn has rowed back from his earlier implication in $R \mathrm{v} A^{71}$ that there is a presumption that Convention rights should override the provisions of other statutes unless there are express words to the contrary. ${ }^{72}$ In Anderson he accepted that re-interpretation "is not available where the suggested interpretation . . . is by implication necessarily contradicted by the statute" ${ }^{73}$

The search to nail down the characteristics indicating such a "contradiction" has also borne fruit. Lord Rogers argued in Ghaidan that section 3 "does not allow the courts to change the substance of a provision completely, to change a provision from one where Parliament says that $\mathrm{x}$ is to happen into one saying $\mathrm{x}$ is not to happen". ${ }^{74}$ In Lord Nichol's terms " $[\mathrm{t}]$ he meaning imported by application of section 3 must be compatible with the underlying thrust of the legislation being construed". ${ }^{75}$

Applying this construction, the phrase in the 1977 Rent Act "as his or her wife or husband" 76 was re-interpreted to mean "as if they were his wife or husband" in Ghaidan. ${ }^{77}$ This was viewed as in line with the thrust of the statute which had already been amended to include cohabiting, as well as married, couples but discriminated against gay and lesbian partners. However to read section 29 of the Crime (Sentences) Act 1997 in Anderson as precluding the Home Secretary from participating in setting the minimum period served by a mandatory life prisoner, was not deemed "possible" when the provision was drafted for that precise purpose. Such an application of section 3, according to Lord Bingham would "not be judicial interpretation but judicial vandalism. ..".78

68 Ghaidan v Ghodin-Mendoza [2004] 2 AC 557, at 27. See also Aileen Kavanagh, "The elusive divide between interpretation and legislation under the Human Rights Act 1998", (2004) 24 Oxford Journal of Legal Studies 259.

69 Ghadian, ibid., at 41.

70 ibid., at 31.

71 N.62.

72 Ibid., at 44. Lord Steyn argued that the boundary where impossibility arises under s. 3 lies when there is a "clear [limit] on Convention rights ... stated in terms".

$73 R$ (Anderson) v Secretary of State for the Home Department [2003] 1 AC 837, para.59 (my emphasis).

74 N.68, at 110 .

75 ibid., para.33 (my emphasis).

76 Para.2, Sch. 1 Rent Act 1977.

77 N.68 at 51.

$78 \mathrm{~N} .73$ at 30 . This is not to suggest that the rationale for applying s.3 or s.4 in any individual case is beyond dispute. The same argument advanced in Anderson 
The fact that a re-interpretation was not "possible" did not mean the courts could do nothing, however, as they would have under the ancien regime. Instead, they made a Declaration under HRA section 4 that section 29 of the 1997 Act was incompatible with ECHR Article 6. The government responded by repealing section 29 to remove the role of the Home Secretary in setting minimum terms of imprisonment. ${ }^{79}$

Declarations of Incompatibility (DoIs) have not been the paper tiger that many critics feared. ${ }^{80}$ They been more frequent than predicted and in virtually all cases have led to changes in the law or in practice. ${ }^{81}$ The higher courts have issued 17 DoIs in five years, of which 11 are still standing. ${ }^{82}$ The

could legitimately have been made against the application of $\mathrm{s} .3$ in $R \mathrm{v} A$ (see n.62 above) whilst, using the logic advanced in Ghaidan, it is possible to make the case that s.3 should have been used to reinterpret s.11(c) of the Matrimonial Clauses Act 1973 in Bellinger $\mathrm{v}$ Bellinger [2003] 2 A.C. 467 to recognise the reassigned gender of Mrs Bellinger, and therefore the lawfulness of her marriage.

79 S.29 of the Crime (Sentences) Act 1997 was repealed by the Criminal Justice Act 2003, ss.303(b)(I), 332 and Sch. 37, Pt 8. Transitional and new sentencing provisions were contained in chap.7 and Sch.21 and 22 of the CJA 2003.

80 David Bonner et al describe "declarations of incompatibility "as "merely a formal, dramatic and public call for something to be done. .." in "Judicial approaches to the Human Rights Act", (2003) 52(3) ICLQ 549 at 562. Tom Hickman stated that "s.4, unlike s.3, decouples rights from remedy" in "Constitutional Dialogue, Constitutional Theories and the Human Rights Act 1998," [2005] Public Law 306 at 327 .

81 Of the Declarations still standing, in five cases the legislation has been amended after the declaration was made $(R(H) \mathrm{v}$ Mental Health Review Tribunal for the North East London Region and Secretary of State for Health [2001] 3 WLR 512 in relation to Mental Health Act 1983, ss.72-73, International Transport Roth GmbH v Secretary of State for the Home Department [2002] 3 WLR 344 in relation to Immigration and Asylum Act 1999, Pt II, $R(D)$ v Secretary of State for Home Department [2003] 1 WLR 1315 in relation to Mental Health Act 1983 s.74, Blood and Tarbuck v Secretary of State for Health (unreported) in relation to Human Fertilisation and Embryology Act 1990 s.28(6)(b) and Bellinger v Bellinger [2003] 2 AC 467 in relation to Matrimonial Causes Act 1973 s.11(c)). In two cases the legislation was repealed after the declaration was made ( $M c R$ 's Application for Judicial Review (2003) NIQB 58 (unreported) in relation to Offences Against the Person Act $1861 \mathrm{~s} .62$ and $R$ (Anderson) v Secretary of State for the Home Department [2003] $1 \mathrm{AC}$ 837). In one case the legislation was repealed before the declaration was made ( $R$ (Wilkinson) $\mathrm{v}$ Inland Revenue Commissioners [2005] 1 WLR 1718 in relation to Income and Corporation Taxes Act 1988 s.262). In one case a commitment has been made to amend the legislation $(R(M)$ v Secretary of State for Health [2003] ACD 389 in relation to Mental Health Act 1983 ss.26-29) and in another case the legislation expired and has not been renewed ( $A$ and others v Secretary of State for the Home Department, [2005] 2 WLR 87 in relation to Anti-Terrorism, Crime and Security Act $2001 \mathrm{~s} .23)$. In the final case the declaration has only recently been upheld $(R$ (Morris) v Westminster City Council and First Secretary of State [2005] EWCA Civ 1184).

82 Six Declarations of Incompatibility have been overturned on appeal ( $R$ (Alconbury Developments Ltd.) v Secretary of State for the Environment, Transport and the Regions [2001] 2 WLR 1389, Wilson v First County Trust Ltd. (No.2) [2004] 1 AC 816, Matthews v Ministry of Defence [2003] 1 AC 1163, R (Uttley) v Secretary of State for the Home Department [2004] 1 WLR 2278, R (Hooper) v 
most notable example was, of course, the House of Lords declaration in December 2004 that section 23 of the Anti-terrorism, Crime and Security Act 2001 was incompatible with ECHR Articles 5 and 14. ${ }^{83}$ The government did not seek to renew the offending provision and the 10 remaining prisoners, who were subject to indefinite detention when Part 4 of the Act expired, were released, although they now remain subject to "control orders" or detention pending deportation.

\section{Addressing the Democratic Deficit}

The scheme of the HRA, relying on a strong interpretive clause combined with the power to issue Declarations of Incompatibility, attracted some scepticism at the outset. Lawyers and constitutional reformers who campaigned for a "constitutional Bill of Rights" argued that without the power to overturn primary legislation, on a par with the American and Canadian Supreme Courts, the executive would remain unaccountable. ${ }^{84}$ Nothing less than a judicial strike down power would adequately address the inadequacies of our democratic system which had been one of the spurs for incorporation. In this vein, the think-tank, the Institute of Public Policy Research, maintained that:

"The need for the entrenchment of rights for individuals . . . implies a constitutional document . . . to change from a single, fundamental principle, the supremacy of Parliament . . . to a fundamental law which is prior to, independent of and the source of authority for the system of government." 85

The contrary view warned against addressing one democratic deficit by creating a new one. Increased accountability of the executive to the judiciary would be at the cost of democratic legitimacy and participation. Professors Keith Ewing and Conor Gearty argued that:

"A Bill of Rights would run counter to democratic instincts. The reason for this is that it empowers the courts to strike down legislation passed by Parliament. The effect would thus be to transfer the ultimate power in the community to the judges ... It is always to be kept in mind that a Bill of Rights has to be interpreted before it can be applied in any particular case." $" 86$

The scheme of the HRA was intended to address this latter criticism, whilst significantly increasing the accountability of the executive to the courts. The adopted approach has sometimes been called a "dialogue model" in that it engages all the major organs of the state in deliberations about fundamental human rights and their interpretation. It significantly enhances the power of the courts to determine that breaches have occurred, but leaves the final say

Secretary of State for Work and Pensions [2005] 1 WLR 1681 and $R(M H) \mathrm{v}$ Secretary of State for Health [2005] UKHL 60).

83 N.40.

84 See also the article by Aidan O'Neill QC in this Special Issue for an analysis of the alternative model in Scotland.

85 IPPR, A Written Constitution for the UK, 1993, p.7.

86 Keith Ewing and Conor Gearty, Democracy or a Bill of Rights, Society of Labour Lawyers, 1991, p.4. 
on legislation with Parliament, albeit a Parliament which is significantly dominated by the government of the day.

The "dialogue model" plays out in particular through the intersection of HRA section 3 and section 4 but there is also a requirement on ministers to state whether new legislation is compatible with ECHR rights under section 19. Although this was initially viewed as a "parrot provision" (every Bill being deemed by ministers to comply) it has grown to be a useful catalyst for nudging Whitehall into a more thorough rights review of new policies and legislation and provides a useful peg on which parliamentarians can hang scrutiny of new Bills. ${ }^{87}$ The most significant effect of this section has been the additional spur it has given to the courts to seek to interpret legislation compatibly, even if this was not always a minister's intention in making a "statement of compatibility" on the face of a Bill. ${ }^{88}$ An example of dialogue in action.

Jack Straw described the HRA model in the following terms:

"Parliament and the judiciary must engage in a serious dialogue about the operation and development of the rights in the Bill ... this dialogue is the only way in which we can ensure the legislation is a living development that assists our citizens." 89

This approach is sometimes enmeshed with a separate but parallel debate on judicial deference, or, as Lord Woolf, former Lord Chief Justice, has put it, the area of judgement "within which the judiciary defer on democratic grounds to the considered opinion of the elected body or person whose actual decision is said to be incompatible with the Convention". ${ }^{90}$ This latter question is often addressed as if the HRA itself was not designed to resolve issues of judicial and executive boundaries. Rather than construct a complicated new doctrine of judicial deference to the legislature, it might be more productive to elicit these principles from the scheme of the HRA itself. ${ }^{91}$ As Richard Clayton QC has argued, "the principle of 'democratic dialogue,' which is implicit in the structural features of the Act" renders "the need to defer to parliament or the executive . . less compelling, once it is

87 Lord Lester QC has commented that "human rights scrutiny is now systematic, influencing the preparation of legislation in Whitehall and the legislative process itself" in "The Human Rights Act 1998: Five Years On," [2004] 3 European Human Rights Law Review 258 at 262. Examples include the Care Standards Act 2000, the Gender Recognition Act 2004 and the Mental Capacity Act 2005.

88 See for example the rationale for Justice Collin's decision that 5.55 of the Nationality, Immigration and Asylum Act 2002 violated ECHR Arts. 3 and 6 in $R$ (Q) v Secretary of State for the Home Department [2003] EWHC 195.

89314 HC 1141 (24 June 1998). (My emphasis). It should be noted, however, that when the senior judiciary gave evidence to the JCHR they distanced themselves from the notion that they were involved in a dialogue with the other organs of the state on fundamental human rights. JCHR, Minutes of Evidence, HC 332-iii, 2001.

90 Lord Woolf, "European Court of Human Rights on the Occasion of the Opening of the Judicial Year," "[2003] 3 European Human Rights Law Review 257 at 260. See also Lord Steyn, "Deference: a tangled story," [2005] Public Law 346.

91 See Francesca Klug "Judicial deference under the Human Rights Act" [2003] European Human Rights Law Review 125. 
acknowledged that the HRA envisages that the other branches of government will have a second bite of the cherry". 92

As we have seen, despite the absence of a legal duty on government to respond to Declarations, in virtually every case the government has changed law or policy as a result. The decision as to what that law or policy should precisely be, however, remains one for Parliament or government. This applies even in relation to section 3 interpretations, in that it is open to Parliament to enact new legislation to modify such interpretations. There may even be occasions, as Jack Straw acknowledged in introducing the Human Rights Bill, where "the Judicial Committee of the House of Lords could make a declaration that, subsequently, Ministers propose and Parliament accepts, should not be accepted". ${ }^{93}$ The example he gave was abortion law, but he might have added fox hunting bans, gun control or election expenditure limits, all of which have been the subject of human rights disputes here or in other jurisdictions.

If the "dialogue model" is to be an effective approach to protecting human rights, rather than a means of retaining unaccountable executive dominance, as supporters of a constitutional bill of rights feared, Parliament needs its own voice, distinguishable from government. ${ }^{94}$ The government White Paper Bringing Rights Home was explicit on this:

"Parliament itself should play a leading role in protecting the

rights which are at the heart of a parliamentary democracy." ${ }^{95}$

Lord Irvine elaborated on this further when he described the HRA as representing a "new and dynamic co-operative endeavour . . . between the Executive, the Judiciary and Parliament; one in which each works in its respective constitutional sphere" ${ }^{96}$ The establishment of the Joint Committee on Human Rights (JCHR) in 2001 has undoubtedly enhanced the awareness of the HRA within Parliament. The Committee has been indefatigable, producing 88 full reports and 3 special ones in four years. ${ }^{97}$ Subjects covered range from the case for a human rights commission to police reform. Some of its reports have clearly been influential, ${ }^{98}$ in a few instances leading to small, but significant, changes in the final shape of

92 Richard Clayton, "Judicial Deference and 'Democratic Dialogue', the legitimacy of judicial intervention under the Human Rights Act 1998", [2004] Public Law 33.

93317 HC 1301 (21 October 1998).

94 See Danny Nicol, "The Human Rights Act and the Politicians," [2004] Legal Studies 451.

95 Bringing Rights Home: Labour's plans to Incorporate the ECHR into UK Law, Labour Party consultation document, 1996.

96 Inaugural Irvine Human Rights Centre Lecture, 1 November 2002, Durham Human Rights Centre, Durham University, published in [2003] Public Law 308.

97 The Committee published its initial report on the Anti-Terrorism, Crime and Security Bill only two days after David Blunkett introduced the Bill on 12 November 2001.

98 Amendments were tabled to several Bills as a consequence of JCHR reports including the Criminal Justice and Police Bill 2001, Nationality, Immigration and Asylum Bill 2002, Courts Bill 2002\#,Crime (International Co-operation) Bill 2002, Housing Bill 2003 and the Mental Capacity Bill 2003. 
legislation. ${ }^{99}$ The JCHR has also succeeded in persuading the government to expand slightly the written information it provides with section 19 "statements of compatibility". ${ }^{100}$ That said, there has, of course been a steady stream of legislation and policy which the Committee deemed in breach of Convention rights and which it has been unable to affect. ${ }^{101}$

\section{Building a Human Rights Culture of Compliance}

What is only occasionally acknowledged, is that underlying the "dialogue approach" to human rights compliance is a particular vision of human rights. It is a different vision to that which informed the American Bill of Rights, drafted to "withdraw certain subjects from the vicissitudes of political controversy". ${ }^{102}$ It is informed by a view of human rights that acknowledges that they are not always, or even usually, absolute but derive from political struggle and thrive on political argument. The purpose of the dialogue model is to keep the idea and dynamic of human rights alive, rather than to close down the debate about them and hive them off to a rarefied court.

Although difficult to evaluate and impossible to quantify, there is evidence that to this degree a culture of human rights awareness, if not compliance, is beginning to be fostered as a result of the HRA. Debates about detention without trial, the morality of deporting suspects to countries where they may be tortured, the ethics of assisted suicide, access to expensive medicines and the degree to which celebrities and politicians have a right to a private life, have arguably all been enlivened by the HRA. The existence of a statute that, for the first time in modern UK history, establishes a set of broad ethical values that inform all other law and policy, provides the potential for a common framework - a touchstone - within which these debates can occur.

A deeper understanding and awareness of human rights values also provides a route to developing the culture of respect for human rights that was presented as the third stated reason for introducing the HRA. The Act is unusual in having a specific clause aimed at public authorities, requiring them to comply with Convention rights. ${ }^{103}$ The Disability Rights

99 The JCHR report on the Anti-Terrorism, Crime and Security Bill led the government to amend the Bill to introduce "reasonable grounds" of suspicion of involvement with "international terrorism" before an individual could be detained. See Fifth Report of Session 2001-02, para.8. Another example is the removal of clause 25 from the Draft Civil Contingencies Bill following criticism from the JCHR and others. Clause 25 provided that a regulation made under Part 2 of the Bill would "be treated as if it were an Act of Parliament" for the purposes of the HRA. See Fifteenth Report of Session 2002-03, para.3.26.

100 The Standing Orders of both Houses were amended in November 2001 to require memorandum attached to each Bill by the promoter to include "a statement of opinion. . . as to the compatibility of the provisions of the bill with the Convention rights. .."

101 For example, the JCHR warned that Part 4 of the Anti-Terrorism, Crime and Security Act 2001 might be found to breach Arts. 5 and 14 of the ECHR (see Second Report of Session 2001-2002, para.38). The House of Lords agreed. See n. 40

102 West Virginia State Board of Education v Barnette 319 US 624 at 638 (1943).

103 HRA s.6(1): "It is unlawful for a public authority to act in a way which is incompatible with a Convention right". 
Commission and organisations like Age Concern, Help the Aged and Values Into Action ${ }^{104}$ have already used the values in the Act to advocate better services for their members and to engage in public debates about what constitutes dignified and just treatment for all. ${ }^{105}$

There is, as yet, no reliable research on public understanding or awareness of the HRA ${ }^{106}$ but an Audit Commission review concluded that "the impact of the Act is in danger of stalling and the initial flurry of activity surrounding its introduction had waned". ${ }^{107}$ In the absence of any institutional support for championing the HRA outside of Northern Ireland, ${ }^{108}$ these findings are perhaps unsurprising. The proposed Commission for Equality and Human Rights (CEHR), whose duties will include promoting "awareness, understanding and protection of human rights"109 and encouraging "public authorities to comply" with HRA section 6 , is scheduled to begin operating in the autumn of 2007. ${ }^{110}$ Although the Commission will not be empowered to support individual human rights cases, unless they also engage antidiscrimination legislation, it will be able to judicially review public authorities for breaches of Convention rights and apply to the courts to

104 VIA promotes the right of people with learning difficulties to be treated with the same respect due to all citizens.

105 See Tessa Harding, 'Rights at Risk: Older people and human rights', Help the Aged, 2005 and the forthcoming report by Frances Butler, 'Rights for Real: Older People, their Human Rights and the Commission for Equality and Human Rights', Age Concern, due to be published 2006.

106 The Department for Constitutional Affairs (DCA) is carrying out research on human rights with users and providers of public services to identify strategies for implementing the principles underlying the Human Rights Act.

107 Audit Commission, Human Right: Improving public service delivery, 2003, para 2. The report states that whilst basic training of staff on the HRA is fairly widespread and growing, $58 \%$ of public bodies surveyed had no corporate human rights strategy.

108 The Northern Ireland Human Rights Commission was created by s.68 of the Northern Ireland Act 1998, in compliance with a commitment made by the British Government in the Belfast (Good Friday) Agreement of 10 April 1998. The Australian Central Territories, which in 2004 introduced a Human Rights Act largely modelled on the UK Human Rights Act, has already established a Human Rights and Discrimination Commissioner to monitor and promote it. The Scottish Commissioner for Human Rights Bill was published in October 2005 and will establish an independent Commissioner to promote awareness, understanding of and respect for human rights in Scotland.

109 Defined as "the Convention rights within the meaning given by s.1 of the Human Rights Act 1998, and other human rights", which includes all other international and regional human rights declarations and treaties. Equality Bill 2005, clause 9(2).

110 Equality Bill 2005, clauses 9(1)(c) and 9(1)(d) respectively. See also Francesca Klug and Claire O'Brien, "'Fairness for All?' An analysis of human rights powers in the White Paper on the proposed Commission for Equality and Human Rights," [2004] Public Law 712. 
intervene in human rights cases. ${ }^{111}$ It will also be able to conduct human rights inquiries, with full powers to subpoena witnesses and call for papers. ${ }^{112}$

The thrust of CEHR's human rights powers are aimed at championing the importance of human rights and creating a culture of compliance amongst public, and relevant private, bodies. The ground-breaking work of the British Institute of Human Rights in pioneering this approach, which will undoubtedly influence the CEHR, is described in a separate article. ${ }^{113}$

\section{Conclusion}

The HRA is still in its infancy. Its impact on the legal system has been considerable. Where once individuals relied on the unwritten common law, and obscure principles of rationality and lawfulness, to protect their unknown rights, they can now challenge any authorities carrying out public functions to uphold their written rights. ${ }^{114}$ This change of approach is starting to seep into public discourse so that debates about moral and ethical dilemmas more often take their bearings from human rights values.

Appreciation of how these values can translate into public policy and inform decision making within public authorities is still in its infancy. With no Commission to lead on this approach, that is to be expected. The proposed CEHR should have the capacity to drive this vision forward. Yet the HRA remains vulnerable. The Conservative Opposition is committed to reviewing the Act with a view to its "reform, replacement or repeal". ${ }^{115}$ The government which introduced it, loudly complains about judges using the HRA to block its programme, ${ }^{116}$ and muses about directing the courts to interpret its provisions differently from the European Court of Human Rights. ${ }^{117}$

If the HRA is to endure like other Bills of Rights, it will need to become embedded in the popular consciousness as a useful tool and as a defining statement of values. But if, as Professor Conor Gearty has argued, the HRA "has the potential effectively to resolve many of the issues of political power

111 Equality Bill 2005, clause 30. The DRC has successfully used intervention powers to extend the reach of human rights law in a number of HRA cases, e.g. $R$ (A and B) v East Sussex County Council, see n.53 and $R$ (Burke) v General Medical Council [2004] EWHC 1879 (Admin) and [2005] EWCA Civ 1003.

112 Equality Bill 2005, clause 16.

113 See the article in this Special Issue by Sarah Cooke former Director of the British Institute of Human Rights.

114 E.g. in the fight to get the drug Herceptin to treat breast cancer, it has been argued that primary care trusts' refusal to pay for the drug breaches human rights legislation and the right to life. The Health Secretary Patricia Hewitt said primary care trusts could not refuse to fund the life-saving drug solely on the grounds of cost. See Telegraph (4 October 2005).

115 "David Davies announces review", Conservative Party website, 23 August 2004.

116 In response to judicial interpretations of the Nationality Immigration and Asylum Act 2002 (n.88) David Blunkett, then Home Secretary said, "I'm fed up with having to deal with a situation where Parliament debates issues and the judges overturn them." Times, 20 February 2003.

117 In the context of the government's stated wish to deport suspected international terrorists to countries which routinely practice torture. "Interview with Charles Clarke, Home Secretary,” New Statesman Special Issue, 26 September 2005. 
204 Northern Ireland Legal Quarterly [Vol. 57, No. 1]

and judicial legitimacy that ... have dogged other jurisdictions with analogous bills of rights" 118 then the long road to human rights compliance is at least in sight.

118 "Reconciling parliamentary democracy and human rights" [2002] 118 LQR, 245. 